\title{
Effects of Amyloid Light-Chain Amyloidosis on Clinical Characteristics and Prognosis in Multiple Myeloma: A Single-Center Retrospective Study
}

This article was published in the following Dove Press journal: Cancer Management and Research

\author{
Junhui $\mathrm{Xu}^{*}$ \\ Mangju Wang* \\ Ye Shen (D) \\ Miao Yan \\ Weiwei Xie \\ Bingjie Wang \\ Huihui Liu \\ Xinan Cen
}

Department of Hematology, Peking University First Hospital, Beijing, People's Republic of China

*These authors contributed equally to this work
Correspondence: Xinan Cen Department of Hematology, Peking University First Hospital, No. 8 Xi Shi Ku Street, Xi Cheng District, Beijing, I00034, People's Republic of China Tel +86-10-83575746

Email cenxn@bjmu.edu.cn
Background: Amyloid light-chain amyloidosis (AL amyloidosis) is commonly associated with multiple myeloma. However, the clinical characteristics and prognosis of symptomatic and smoldering multiple myeloma with AL amyloidosis are not particularly clear.

Methods: Patients with symptomatic and smoldering multiple myeloma in the Peking University First Hospital registry from 2010 to 2018 were studied. The clinical and laboratory information was collected from first presentation to death or until the last available clinical follow-up. The patients' survival and outcomes were analyzed, and the relationship between the clinical parameters and survival was also assessed.

Results: Compared with symptomatic multiple myeloma patients without AL amyloidosis, patients with $\mathrm{AL}$ amyloidosis had higher incidence of $\mathrm{BNP} \geqq 700 \mathrm{pg} / \mathrm{mL} \quad(P<0.001)$, ALP $>187.5 \mathrm{IU} / \mathrm{L}(P=0.032)$ and $\mathrm{ALB}<25 \mathrm{~g} / \mathrm{L}(P<0.001)$. Similarly, compared with smoldering multiple myeloma patients without $\mathrm{AL}$ amyloidosis, patients with $\mathrm{AL}$ amyloidosis had higher incidence of $\mathrm{BNP} \geqq 700 \mathrm{pg} / \mathrm{mL}(P=0.030)$ and $\mathrm{Alb}<25 \mathrm{~g} / \mathrm{L}(P=0.024)$. The existence of $\mathrm{AL}$ amyloidosis, especially those with the heart involvement, was related to shorter long-term survival of symptomatic and smoldering multiple myeloma according to univariate analyses. Renal involvement and gastrointestinal tract involvement had an impact on the prognosis of smoldering multiple myeloma but not on the symptomatic multiple myeloma. Cox regression model for overall survival detected $\mathrm{BNP} \geqq 700 \mathrm{pg} / \mathrm{mL}$ in symptomatic multiple myeloma having independent poorer prognostic significance $(\mathrm{HR}=2.455, P=0.004)$. Interestingly, $\mathrm{BNP}$ at diagnosis was significantly correlated with cardiac amyloidosis $(\mathrm{r}=0.496, P<0.001)$. Cox regression model for overall survival detected the presence of $\mathrm{AL}$ amyloidosis in smoldering multiple myeloma having independent poorer prognostic significance $(\mathrm{HR}=8.741, P=0.002)$.

Conclusion: $\mathrm{AL}$ amyloidosis is an independent poor prognostic factor for not only symptomatic multiple myeloma but also smoldering multiple myeloma. It is mainly because of involvement of important organs, especially the heart. AL amyloidosis probably has a greater impact on the prognosis of smoldering multiple myeloma than on the symptomatic multiple myeloma.

Keywords: symptomatic multiple myeloma, smoldering multiple myeloma, AL amyloidosis, poor prognostic factor

\section{Background}

Multiple myeloma is divided into symptomatic multiple myeloma and smoldering multiple myeloma. Symptomatic multiple myeloma is mainly manifested by abnormal proliferation of bone marrow plasma cells and accompanied by large amounts of $\mathrm{M}$ protein secretion or light chain, leading to hypercalcemia, renal injury, anemia and bone destruction. ${ }^{1}$ Compared with symptomatic multiple myeloma, smoldering 
multiple myeloma did not have CRAB (hypercalcemia, renal injury, anemia and bone destruction) and SLiM (clonal bone marrow plasma cell percentage $\geq 60 \%$, involved: uninvolved serum free light-chain ratio $\geq 100,>$ one focal lesions on magnetic resonance imaging studies). Many prognostic factors have been analyzed in multiple myeloma. Some studies have found that age, albumin, hypercalcemia, lactate dehydrogenase, bone marrow plasma cell ratio, serum-involved/uninvolved FLC ratio, $\beta 2$-microglobulin, D-S stage, ISS stage and high-risk cytogenetic abnormalities are significantly associated with the prognosis of symptomatic multiple myeloma. ${ }^{2-9}$ In addition, some studies have found that bone marrow plasma cell ratio, aPC/BMPC (abnormal plasma cell/bone marrow plasma cell ratio), peripheral circulating plasma cells, M-protein, serum-involved/uninvolved FLC ratio, highrisk cytogenetic abnormalities are significantly associated with the prognosis of smoldering multiple myeloma. ${ }^{10}$

$\mathrm{AL}$ amyloidosis (ALA) is a rare and poorly prognostic disease that is clearly associated with monoclonal gammopathy of unknown significance, multiple myeloma and Waldenström macroglobulinemia. ${ }^{11}$ The abnormal plasma cells of the above plasma cell diseases secrete a large number of light chains, which deposit in various organs and become amyloid proteins, causing damage to the organs. ${ }^{11}$ The organs usually affected are skin, soft tissue, kidney, liver, heart, gastrointestinal tract and peripheral nerves. ${ }^{12}$ The median survival time for AL amyloidosis is $2-3$ years. ${ }^{13}$ Its prognosis is related to the number and degree of involvement of the affected organs, especially cardiac amyloidosis. In clinical practice, we often use the 2004 and 2012 Mayo Clinical AL Amyloidosis Staging System including NT-proBNP (N terminal pro B type natriuretic peptide), CTNI (Cardiac troponin I) and dFLC (difference between involved and uninvolved serum free light chains) largely representing the severity of cardiac amyloidosis to stratify patients with AL amyloidosis. ${ }^{14,15}$

Whether and how AL amyloidosis affects the clinical characteristics and survival time of multiple myeloma were rarely studied. Only four studies have been reported. ${ }^{16-19}$ The results of these studies were affected by the characteristics of the included population and treatment plans. In general, these studies had found that AL amyloidosis was a poor prognostic factor for multiple myeloma. Whether AL amyloidosis has the same effect on symptomatic multiple myeloma and smoldering multiple myeloma or not is unclear. Moreover, there is currently no study to respectively explore the effects of $\mathrm{AL}$ amyloidosis on the clinical features and prognosis of symptomatic multiple myeloma and smoldering multiple myeloma. Therefore, we collected the clinical information and follow-up data to deal with this question.

\section{Methods}

\section{Patients and Institutional Review Board Approval}

We included 188 patients with multiple myeloma registered from January 1, 2010 to December 31, 2018. One hundred and fifty-eight patients were included in the subsequent analyses. The exclusion criteria were as follows: 1) patients with plasma cell diseases such as monoclonal gammopathy of unknown significance and Waldenström macroglobulinemia; 2) ten patients with incomplete data and the diagnosis interval of AL amyloidosis and multiple myeloma more than one month were excluded; and 3) 20 patients were lost during follow-up. Multiple myeloma was diagnosed according to the 2014 International Myeloma Working Group criteria. ${ }^{20}$ The symptomatic multiple myeloma and smoldering multiple myeloma were both included in this study. The disease definition of symptomatic multiple myeloma was as follows: clonal bone marrow plasma cells $\geq 10 \%$ or biopsy-proven bony or extramedullary plasmacytoma with any one or more of the following myeloma defining events: CRAB (serum calcium higher than $>2.75 \mathrm{mmol} / \mathrm{L}$, serum creatinine $>177 \mu \mathrm{mol} / \mathrm{L}$, haemoglobin value of $>20 \mathrm{~g} / \mathrm{L}$ below the lower limit of normal, one or more osteolytic lesions on skeletal X-ray, computed tomography, or positron emission tomography/computed tomography) and/or SLiM (clonal bone marrow plasma cell percentage $\geq 60 \%$, involved: uninvolved serum free light-chain ratio $\geq 100$, > one focal lesion on magnetic resonance imaging studies). The patients were diagnosed as smoldering multiple myeloma if the following three items were met: clonal bone marrow plasma cells $10-60 \%$, serum monoclonal protein (IgG or $\operatorname{IgA}) \geq 30 \mathrm{~g} / \mathrm{L}$ or urinary monoclonal protein $\geq 500 \mathrm{mg}$ per $24 \mathrm{~h}$, absence of CRAB and SLiM. AL amyloidosis was confirmed by the light and polarized microscopy for the presence of Congo red deposits and green birefringence of the biopsies of affected parts, including skin, heart, liver, kidney, gastrointestinal tract, bone marrow, subcutaneous fat and rectal mucosa. Besides, immunohistochemistry was required to confirm the presence of monoclonal light chains. The organ involvement for $\mathrm{AL}$ amyloidosis was assessed as per the 
consensus criteria reported in the 10th International Symposium on Amyloid and Amyloidosis: kidney (24-hr urine protein $>0.5 \mathrm{~g} /$ day, predominantly albumin), heart (echocardiogram: mean wall thickness $>12 \mathrm{~mm}$, no other cardiac cause), liver (total liver span $>15 \mathrm{~cm}$ in the absence of heart failure or alkaline phosphatase $>1.5$ times institutional upper limit of normal), nerve (symmetric lower extremity sensorimotor peripheral neuropathy, gastric-emptying disorder, pseudo-obstruction, voiding dysfunction not related to direct organ infiltration), gastrointestinal tract (direct biopsy verification with symptoms), lung (direct biopsy verification with symptoms), soft tissue (tongue enlargement, arthropathy, claudication, presumed vascular amyloid, skin, myopathy by biopsy or pseudohypertrophy, lymph node and carpal tunnel syndrome). ${ }^{21}$ Written informed consent was obtained from each individual participant. This study was approved by the institutional review board (IRB) of Peking University First Hospital. This study was conducted in accordance with the Declaration of Helsinki.

\section{Data Collection}

Clinical profiles of patients were obtained through retrospective reviews of hospital files. We extracted the following clinical information at the time of diagnosis retrospectively for all patients: lactate dehydrogenase (LDH), hemoglobin $(\mathrm{Hb})$, calcium $(\mathrm{Ca})$, albumin (ALB), alkaline phosphatase (ALP), serum creatinine (Scr), brain natriuretic peptide (BNP) and quantification of immunoglobulin and urinary monoclonal protein. Higher LDH was defined as $\mathrm{LDH} \geqq 240 \mathrm{IU} / \mathrm{L}$. Serious anemia was defined as $\mathrm{Hb}<85 \mathrm{~g} / \mathrm{L}$. Hypercalcemia was defined as calcium $\geqq 2.75 \mathrm{mmol} / \mathrm{L}$. Severe hypoalbuminemia was defined as albumin less than $25 \mathrm{~g} / \mathrm{L}$. The cutoff of ALP was 187.5IU/L which was the diagnostic criteria of liver involvement of AL amyloidosis. Renal dysfunction was defined as Scr $\geqq 177 \mu \mathrm{mol} / \mathrm{L}$. The cutoff of BNP was $700 \mathrm{pg} / \mathrm{mL}$ which represented severe cardiac amyloidosis. In addition, X-ray, Computed tomography, magnetic resonance imaging (MRI) or positron emission tomography/computed tomography (PET-CT) were used to determine bone destruction. Severe bone destruction was defined as bone destruction more than three lesions. Bone puncture was performed to determine the bone marrow plasma cells (BMPC) ratio. Higher BMPC was defined as BMPC more than 20\%. Immunofixation electrophoresis was performed to identify the type of light chain involved. D-S stage of multiple myeloma was then determined based on the above-mentioned information. Worse D-S stage was defined as Stage III.

\section{Treatment, Initial Therapeutic Effect and Follow-Up}

The patients were treated with different kinds of treatment regimens, such as BD (bortezomib and dexamethasone), MP (melphalan and prednisone), RD (lenalidomide and dexamethasone), TD (thalidomide and dexamethasone), VAD (vincristine plus adriamycin and dexamethasone), PAD (bortezomib plus doxorubicin and dexamethasone), RVD (bortezomib plus lenalidomide and dexamethasone), MPT (melphalan plus prednisone and thalidomide), BCD (bortezomib plus cyclophosphamide and dexamethasone) and BTD (bortezomib plus thalidomide and dexamethasone). This study divided the treatment regimens into bortezomib group including BD, PAD, RVD, BCD, BTD and non-bortezomib group including MP, TD, RD, VAD, MPT. Some patients refused chemotherapy due to economic factors and adopt conservative treatment measures. These patients were assigned to non-bortezomib group. Initial therapeutic effect (ITE) was defined as the response of multiple myeloma after four courses. We evaluated the initial therapeutic effect of multiple myeloma using the 2016 International Myeloma Working Group consensus criteria for response, including stringent complete response (sCR), complete response (CR), very good partial response (VGPR), partial response (PR), minimal response (MR), stable disease (SD) and progressive disease (PD). ${ }^{22}$ Better ITE was defined as better than MR including PR, VGPR, CR and sCR. The initial therapeutic effect of patients who did not receive treatment was evaluated as progressive disease. Survival data of patients were obtained through retrospective reviews of hospital files and telephone interviews. Loss of follow-up was defined as the inability to communicate with the patient on the phone, resulting in loss of survival data. Overall survival time was defined as the time from the diagnosis to the time of death (despite the cause of death), or the last-documented contact with the patient. Multiple myeloma-related death included infection, renal failure, heart failure, hypercalcemia, hemorrhage, plasma cell leukemia and amyloidosis. Among them, AL amyloidosis-related death included cardiac amyloidosis (heart failure and arrhythmia), renal failure caused by renal amyloidosis, digestive tract hemorrhage caused by digestive tract involvement.

\section{Statistical Analyses}

Chi-square and Fisher's exact tests were used to compare the categorical variables in different groups of patients, including multiple myeloma with and without $\mathrm{AL}$ amyloidosis, and 
AL amyloidosis with different light-chain types. Categorical variables were reported as numbers and percentages. Overall survival curves were analyzed using the Kaplan-Meier method and compared by Log rank test for univariate analysis. Factors with $P<0.10$ on univariate analyses or acknowledged meaningful in the clinic were included in the multivariate analysis. Multivariate analyses were performed with Cox proportional hazards. The KolmogorovSmirnov test was used to determine whether the data were normally distributed or not. Correlation analyses between BNP and cardiac amyloidosis were performed with Spearman correlation test in symptomatic multiple myeloma. $P<0.05$ is considered statistically significant. All analyses were performed using SPSS 20.0 software (SPSS Institute).

\section{Results}

\section{Clinical Characteristics of Multiple Myeloma with or without AL Amyloidosis}

We recruited 158 multiple myeloma patients in our study from January 1, 2010 to December 31, 2018. The clinical characteristics of all the patients are shown in Table 1.There were 36 smoldering multiple myeloma patients and 122 symptomatic multiple myeloma patients. Among them, 49 patients $(31 \%)$ were diagnosed with AL amyloidosis. There were 21 AL patients in smoldering multiple myeloma and 28 AL patients in symptomatic multiple myeloma. Table 2 lists the clinical characteristics of symptomatic multiple myeloma patients with or without AL amyloidosis at the time of diagnosis. The two groups showed similar incidence of serious anemia, severe bone destruction, hypercalcemia, renal dysfunction, severe hypoalbuminemia, higher BMPC, higher LDH, worse D-S stage, treatment regimens and better initial therapeutic effect. Compared with the patients without $\mathrm{AL}$ amyloidosis, patients with $\mathrm{AL}$ amyloidosis showed higher incidence of $\mathrm{BNP} \geqq 700 \mathrm{pg} / \mathrm{mL}(46.4 \%$ vs $10.6 \%$, $P<0.001)$, ALP $>187.5 \mathrm{IU} / \mathrm{L}(14.2 \%$ vs $2.1 \%, P=0.035)$ and $\mathrm{ALB}<25 \mathrm{~g} / \mathrm{L}(39.2 \%$ vs $10.6 \%, P<0.001)$. Table 3 lists the clinical characteristics of smoldering multiple myeloma patients with or without $\mathrm{AL}$ amyloidosis at the time of diagnosis. Similarly, compared with the patients without AL amyloidosis, patients with AL amyloidosis also only showed higher incidence of $\mathrm{BNP} \geqq 700 \mathrm{pg} / \mathrm{mL}(28.5 \%$ vs $0 \%, P=0.030)$ and $\mathrm{ALB}<25 \mathrm{~g} / \mathrm{L}(42.8 \%$ vs $6.7 \%, P=0.024)$.

\section{Clinical Characteristics of Multiple Myeloma with Different Light-Chain Types of AL Amyloidosis}

We observed more patients with multiple myeloma had $\lambda$ type AL amyloidosis $(\mathrm{N}=35,71.5 \%)$ than $\kappa$-type AL amyloidosis $(\mathrm{N}=14,28.5 \%)$. We then further compared the clinical characteristics of multiple myeloma patients with different light-chain types of AL amyloidosis (Table 4). There were no significant differences $(P>0.05)$ in the incidence of severe bone destruction, hypercalcemia, $\mathrm{LDH} \geqq 240 \mathrm{IU} / \mathrm{L}$ or bone marrow plasma cells $\geqq 20 \%$ between the two groups. Patients with $\kappa$-type amyloidosis

Table I Clinical Characteristics of I58 Patients with Multiple Myeloma

\begin{tabular}{|c|c|c|c|}
\hline & Multiple Myeloma $(n=\mid 58)$ & $*^{*}$ Amyloidosis ${ }^{\text {pos }}(\mathbf{N}=49)$ & †Amyloidosis ${ }^{\text {neg }}(n=109)$ \\
\hline Age $\geqq 65(\%)$ & $44(27.8 \%)$ & $13(26.5 \%)$ & $3 \mathrm{I}(28.4 \%)$ \\
\hline Sex=Male $(\%)$ & II3(7I.5\%) & $34(69.3 \%)$ & 79(72.4\%) \\
\hline Serious anemia $(\%)$ & $37(23.4 \%)$ & $7(14.2 \%)$ & $30(27.5 \%)$ \\
\hline Severe bone destruction (\%) & $83(52.5 \%)$ & $19(38.7 \%)$ & $64(58.7 \%)$ \\
\hline Hypercalcemia (\%) & $25(15.8 \%)$ & $3(6.1 \%)$ & $22(20.1 \%)$ \\
\hline Renal insufficiency (\%) & $49(31.0 \%)$ & II (22.4\%) & $38(34.8 \%)$ \\
\hline ALP> 187.5IU/L (\%) & $9(5.6 \%)$ & $7(14.2 \%)$ & $2(1.8 \%)$ \\
\hline Severe hypoalbuminemia (\%) & $31(19.6 \%)$ & $20(40.8 \%)$ & $1 \mathrm{I}(10.1 \%)$ \\
\hline Higher LDH (\%) & $28(17.7 \%)$ & $13(26.5 \%)$ & $15(13.7 \%)$ \\
\hline $\mathrm{BNP} \geqq 700 \mathrm{pg} / \mathrm{mL}(\%)$ & $29(18.3 \%)$ & $19(38.7 \%)$ & $10(9.1 \%)$ \\
\hline Higher BMPC (\%) & $94(59.4 \%)$ & $21(42.8 \%)$ & $73(66.9 \%)$ \\
\hline Affected light-chain types $=\lambda(\%)$ & $88(55.6 \%)$ & $35(72.9 \%)$ & $53(48.6 \%)$ \\
\hline Smoldering multiple myeloma (\%) & $36(22.7 \%)$ & $21(42.8 \%)$ & $15(\mid 3.7 \%)$ \\
\hline \multicolumn{4}{|l|}{ D-S staging } \\
\hline I+II (\%) & $23(\mid 4.5 \%)$ & $5(10.2 \%)$ & $18(16.5 \%)$ \\
\hline III (\%) & $99(62.6 \%)$ & $23(46.9 \%)$ & $76(69.7 \%)$ \\
\hline
\end{tabular}

Abbreviations: *Amyloidosis ${ }^{\text {pos }}$, multiple myeloma with amyloidosis; †Amyloidosis ${ }^{\text {neg }}$, multiple myeloma without amyloidosis; ALP, alkaline phosphatase; LDH, lactate dehydrogenase; BNP, brain natriuretic peptide; BMPC, bone marrow plasma cells ratio; D-S staging, Durie Salmon staging. 
Table 2 Clinical Characteristics of Symptomatic Multiple Myeloma with or without AL Amyloidosis

\begin{tabular}{|c|c|c|c|}
\hline & $*^{*}$ Amyloidosis ${ }^{\text {pos }} \mathbf{N}=\mathbf{2 8}$ & †Amyloidosis ${ }^{\text {neg }} \mathbf{N}=94$ & $\mathbf{P}$ \\
\hline $\mathrm{Age} \geqq 65(\%)$ & $5(17.8)$ & $27(28.7)$ & 0.251 \\
\hline Sex=Male $(\%)$ & $18(64.2)$ & $69(73.4)$ & 0.349 \\
\hline Serious anemia (\%) & $7(25.0)$ & $30(31.9)$ & 0.485 \\
\hline Severe bone destruction (\%) & $19(67.8)$ & $64(68.0)$ & 0.982 \\
\hline Hypercalcemia (\%) & $3(10.7)$ & $22(23.4)$ & 0.144 \\
\hline Renal insufficiency (\%) & II (39.2) & $38(40.4)$ & 0.914 \\
\hline ALP> $187.51 U / L(\%)$ & $4(14.2)$ & $2(2.1)$ & 0.035 \\
\hline Severe hypoalbuminemia (\%) & II (39.2) & $10(10.6)$ & $<0.001$ \\
\hline Higher LDH (\%) & $9(32.1)$ & $14(14.8)$ & 0.076 \\
\hline $\mathrm{BNP} \geqq 700 \mathrm{pg} / \mathrm{mL}(\%)$ & $13(46.4)$ & $10(10.6)$ & 0.001 \\
\hline Higher BMPC (\%) & $16(57.1)$ & $69(73.4)$ & 0.100 \\
\hline Affected light-chain types $=\lambda(\%)$ & $17(60.7)$ & $45(47.8)$ & 0.233 \\
\hline \multicolumn{4}{|l|}{ D-S staging } \\
\hline I+II (\%) & $5(17.8)$ & $18(19.1)$ & 0.878 \\
\hline III (\%) & $23(82.2)$ & $76(80.9)$ & \\
\hline
\end{tabular}

Note: The bold font represents statistical significance.

Abbreviations: $*$ Amyloidosis ${ }^{\text {pos }}$, symptomatic multiple myeloma with amyloidosis; $\nmid$ Amyloidosis $^{\text {neg }}$, symptomatic multiple myeloma without amyloidosis; ALP, alkaline phosphatase; LDH, lactate dehydrogenase; BNP, brain natriuretic peptide; BMPC, bone marrow plasma cells ratio; D-S staging, Durie Salmon staging.

Table 3 Clinical Characteristics of Smoldering Multiple Myeloma with or without AL Amyloidosis

\begin{tabular}{|c|c|c|c|}
\hline & $*^{\text {Amyloidosis }}{ }^{\text {pos }} \mathbf{N}=\mathbf{2}$ I & †Amyloidosis ${ }^{\text {neg }} \mathbf{N}=15$ & $\mathbf{P}$ \\
\hline Age $\geqq 65(\%)$ & $8(38.0)$ & $4(26.7)$ & 0.473 \\
\hline Sex=Male (\%) & $16(76.1)$ & $10(66.7)$ & 0.709 \\
\hline ALP> $187.5 I U / L(\%)$ & $3(14.2)$ & $0(0.0)$ & 0.250 \\
\hline Severe hypoalbuminemia (\%) & $9(42.8)$ & I (6.7) & 0.024 \\
\hline Higher LDH (\%) & $4(19.0)$ & I (6.7) & 0.376 \\
\hline $\mathrm{BNP} \geqq 700 \mathrm{pg} / \mathrm{mL}(\%)$ & $6(28.5)$ & $0(0.0)$ & 0.030 \\
\hline Higher BMPC (\%) & $5(23.8)$ & $4(26.7)$ & 1.000 \\
\hline Affected light-chain types $=\lambda(\%)$ & I8 (85.7) & $8(53.3)$ & 0.058 \\
\hline
\end{tabular}

Note: The bold font represents statistical significance.

Abbreviations: *Amyloidosis ${ }^{\text {pos }}$, smoldering multiple myeloma with amyloidosis; †Amyloidosis ${ }^{\text {neg }}$, smoldering multiple myeloma without amyloidosis; ALP, alkaline phosphatase; LDH, lactate dehydrogenase; BNP, brain natriuretic peptide; BMPC, bone marrow plasma cells ratio.

had a higher incidence of serious anemia than $\lambda$-type amyloidosis $(35.7 \%$ vs $5.7 \%, P=0.024)$. There was no difference in the incidence of $\mathrm{ALB}<25 \mathrm{~g} / \mathrm{L}$ between the two groups, but $\kappa$-type AL amyloidosis patients had significantly higher incidence of renal insufficiency $(50.0 \%$ vs $11.4 \%, P=0.011)$. Patients with $\kappa$-type $\mathrm{AL}$ amyloidosis had a higher incidence of $\mathrm{BNP} \geq 700 \mathrm{pg} / \mathrm{mL} \quad(64.2 \%$ vs $28.5 \%, P=0.020$ ). No statistically significant difference was observed for ALP $>187.5 \mathrm{IU} / \mathrm{L}$ between the two groups (28.5\% vs $8.5 \%, P=0.071)$.

\section{Pathological Biopsy of AL Amyloidosis}

AL amyloidosis was confirmed from pathological biopsies at $\geq$ one body part. Bone marrow biopsy was performed in all 49 patients with AL amyloidosis, and 17 patients
(34.6\%) were positive. Six of nine patients $(66.6 \%)$ were positive for the subcutaneous abdominal fat pad aspirates biopsy. Renal biopsy was performed in 28 patients, and all the patients were positive. Among the 21 patients with smoldering multiple myeloma accompanied by AL amyloidosis, 6 patients with positive renal biopsies were negative for bone marrow biopsies and 1 patient with positive renal biopsy was negative for subcutaneous abdominal fat pad aspirate. Among the 28 patients with symptomatic multiple myeloma accompanied by AL amyloidosis, 15 patients with positive renal biopsies were negative for bone marrow biopsies and one patient with renal biopsy was negative for subcutaneous abdominal fat pad aspirate. Histologic confirmation of AL amyloidosis at other sites was obtained for the six patients that were undetermined 
Table 4 Clinical Characteristics of Multiple Myeloma Patients with Different Light-Chain Types of AL Amyloidosis

\begin{tabular}{|l|l|l|l|}
\hline & $\begin{array}{l}\text { Lambda } \\
(\mathbf{N = 3 5 )}\end{array}$ & $\begin{array}{l}\text { Kappa } \\
\mathbf{( N = 1 4 )}\end{array}$ & $\mathbf{P}$ \\
\hline Age $\geqq 65(\%)$ & $9(25.7)$ & $4(28.5)$ & 0.838 \\
Sex=Male (\%) & $26(74.2)$ & $8(57.1)$ & 0.396 \\
Serious anemia (\%) & $2(5.7)$ & $5(35.7)$ & $\mathbf{0 . 0 2 4}$ \\
Severe bone destruction (\%) & $13(37.1)$ & $6(42.8)$ & 0.711 \\
Hypercalcemia (\%) & $1(2.8)$ & $2(14.2)$ & 0.396 \\
Renal insufficiency (\%) & $4(11.4)$ & $7(50.0)$ & $\mathbf{0 . 0 1 1}$ \\
Higher LDH (\%) & $8(22.8)$ & $5(35.7)$ & 0.357 \\
Higher BMPC (\%) & $14(31.4)$ & $7(50.0)$ & 0.523 \\
Severe hypoalbuminemia (\%) & $16(45.7)$ & $4(28.5)$ & 0.435 \\
Alkaline phosphatase>187.5IU/L (\%) & $3(8.5)$ & $4(28.5)$ & 0.071 \\
Brain natriuretic peptide $\geqq 700 \mathrm{pg} / \mathrm{mL}(\%)$ & $10(28.5)$ & $9(64.2)$ & $\mathbf{0 . 0 2 0}$ \\
\hline
\end{tabular}

Note: The bold font represents statistical significance.

Abbreviations: LDH, lactate dehydrogenase; BMPC, bone marrow plasma cells.

from the bone marrow, subcutaneous abdominal fat and the renal biopsies, including two tongue biopsies, one liver biopsy, one myocardial biopsy, one nerve biopsy and one gastrointestinal tract biopsy.

\section{Organ Involvement}

Organ involvement among the 49 patients with multiple myeloma and AL amyloidosis was as follows: kidney (36, $73.4 \%)$, heart $(27,55.1 \%)$, liver $(13,26.5 \%)$, skin $(8$, $16.3 \%)$, gastrointestinal tract $(6,12.2 \%)$, soft tissue (4, $8.2 \%)$, nerve $(4,8.2 \%)$, and pulmonary $(1,2 \%)$. Thirtyfour patients $(69.4 \%)$ had one or two organs involved and $15(30.6 \%)$ patients had $\geq 3$ organs involved. Eighteen of 36 patients with kidney involvement had heart involvement. Ten of 13 patients with liver involvement also had heart involvement. Five of 6 patients with gastrointestinal tract involvement also had heart involvement. Organ involvement among the 28 patients with symptomatic multiple myeloma and AL amyloidosis was as follows: kidney $(20,71.4 \%)$, heart $(17,60.7 \%)$, liver $(7,25.0 \%)$, skin $(4,14.3 \%)$, gastrointestinal tract $(5,17.8 \%)$, soft tissue $(2,7.1 \%)$, nerve $(2,7.1 \%)$, and pulmonary $(1$, $3.6 \%)$. Eighteen patients $(64.2 \%)$ had one or two organs involved and $10(35.8 \%)$ patients had $\geq 3$ organs involved. In addition, organ involvement among the 21 patients with smoldering multiple myeloma and AL amyloidosis was as follows: kidney $(16,76.1 \%)$, heart $(10,47.6 \%)$, liver $(6$, $28.5 \%)$, skin $(4,19 \%)$ gastrointestinal tract $(1,4.7 \%)$, soft tissue $(2,9.5 \%)$, nerve $(2,9.5 \%)$, and pulmonary $(0,0 \%)$. Sixteen patients $(76.2 \%)$ had one or two organs involved and $5(23.8 \%)$ patients had $\geq 3$ organs involved.

\section{Death Rate and Causes of Death in} Patients with and without AL Amyloidosis Regarding the death rate, 54 of the 109 (49.5\%) patients without AL amyloidosis died during study period. All these patients died of multiple myeloma. Thirty-one of the 49 (63.3\%) patients with AL amyloidosis died during the study period, including $19 / 34$ patients $(55.8 \%)$ with one or two organ involvement and 12/15 patients $(80 \%)$ with $\geq 3$ organ involvement died. Specifically, 19/26 (73.0\%) patients with heart involvement died. All 13 patients with liver involvement died, six of which died of cardiac amyloidosis. Twenty-four of the 36 patients (66.7\%) with kidney involvement died, 12 of which died of cardiac amyloidosis. Five of six patients (83.3\%) with gastrointestinal tract involvement died, three of which died of cardiac amyloidosis. Causes of death are shown in Table 5. Twelve patients did not have clear causes of death, among the remaining 19 patients, 13 died of cardiac amyloidosis, making it the leading cause of death. Other causes include renal failure caused by renal amyloidosis (2), digestive tract hemorrhage caused by digestive tract involvement (2), and other MM-related deaths such as infection and hypercalcemia (2).

\section{Survival Analyses of Patients with Symptomatic Multiple Myeloma}

The Median follow-up time was 57 months (38.6-75.3 months). Fifty-four of the 122 patients (44.2\%) died during the follow-up. The overall median survival time for patients was 37.0 months (25.0-48.9 months). We divided the patients by the clinical characteristics to study the factors affecting symptomatic multiple myeloma patients' survival. Survival time was significantly shorter in patients with $\quad \mathrm{ALP}>187.5 \mathrm{IU} / \mathrm{L}, \quad \mathrm{ALB}<25 \mathrm{~g} / \mathrm{L}, \quad \mathrm{LDH} \geqq 240 \mathrm{IU} / \mathrm{L}$,

Table 5 Causes of Death in All Patients with Multiple Myeloma Accompanied by AL Amyloidosis

\begin{tabular}{|l|l|l|}
\hline & $\begin{array}{l}\text { Number of } \\
\text { Deaths }\end{array}$ & *Proportion \\
\hline Cardiac amyloidosis & 13 & $68.41 \%$ \\
Gastrointestinal bleeding & 2 & $10.53 \%$ \\
(gastrointestinal involvement) & & \\
Renal failure (renal amyloidosis) & 2 & $10.53 \%$ \\
Multiple myeloma-related deaths & 2 & $10.53 \%$ \\
Unknown causes of death & 12 & \\
Deaths & 31 & \\
\hline
\end{tabular}

Abbreviation: *Proportion, proportion of known causes of death. 
Table 6 Survival Analyses of 122 Patients with Symptomatic Multiple Myeloma

\begin{tabular}{|c|c|c|c|c|}
\hline \multirow[t]{2}{*}{ Variables } & \multicolumn{2}{|l|}{ Univariate } & \multicolumn{2}{|l|}{ Multivariate } \\
\hline & OS HR(95\% Cl) & P-value & $\begin{array}{l}\text { OS HR(95\% } \\
\text { Cl) }\end{array}$ & P-value \\
\hline $\begin{array}{l}\text { Sex }=\text { male } \\
\text { Yes } \\
\text { No }\end{array}$ & $1.448(0.83 \mathrm{I}-2.526)$ & 0.192 & & \\
\hline $\begin{array}{l}\text { Age } \\
\geqq 65 \text { years } \\
<65 \text { years }\end{array}$ & $1.443(0.858-2.425)$ & 0.166 & & \\
\hline $\begin{array}{l}\text { Severe bone } \\
\text { destruction } \\
\text { Yes } \\
\text { No }\end{array}$ & $1.316(0.764-2.267)$ & 0.322 & & \\
\hline $\begin{array}{l}\text { Hypercalcemia } \\
\text { Yes } \\
\text { No }\end{array}$ & $1.273(0.69 \mid-2.344)$ & 0.439 & & \\
\hline $\begin{array}{l}\text { Renal injury } \\
\text { Yes } \\
\text { No }\end{array}$ & I.422(0.864-2.34I) & 0.166 & & \\
\hline $\begin{array}{l}\text { Serious anemia } \\
\text { Yes } \\
\text { No }\end{array}$ & $1.326(0.792-2.218)$ & 0.283 & & \\
\hline $\begin{array}{l}\text { Higher BMPC } \\
\text { Yes } \\
\text { No }\end{array}$ & $0.824(0.496-1.367)$ & 0.453 & & \\
\hline $\begin{array}{l}\text { Worse D-S stage } \\
\text { Yes } \\
\text { No }\end{array}$ & $1.883(0.898-3.951)$ & 0.094 & & \\
\hline $\begin{array}{l}\text { ALP>187.5IU/L } \\
\text { Yes } \\
\text { No }\end{array}$ & $\begin{array}{l}7.781 \\
(3.156-19.183)\end{array}$ & $<0.001$ & & \\
\hline $\begin{array}{l}\text { Severe } \\
\text { hypoalbuminemia } \\
\text { Yes } \\
\text { No }\end{array}$ & $2.147(1.214-3.797)$ & 0.009 & & \\
\hline $\begin{array}{l}B N P \geqq 700 \mathrm{pg} / \mathrm{mL} \\
\text { Yes } \\
\text { No }\end{array}$ & $1.764(0.990-3.142)$ & 0.048 & $\begin{array}{l}2.455 \\
(1.339-4.501)\end{array}$ & 0.004 \\
\hline $\begin{array}{l}\text { Higher LDH } \\
\text { Yes } \\
\text { No }\end{array}$ & $1.881(1.052-3.363)$ & 0.033 & & \\
\hline $\begin{array}{l}\text { AL amyloidosis } \\
\text { Yes } \\
\text { No }\end{array}$ & $1.854(1.074-3.200)$ & 0.027 & & \\
\hline $\begin{array}{l}\text { Better ITE } \\
\text { Yes } \\
\text { No }\end{array}$ & $0.126(0.070-0.226)$ & $<0.001$ & $\begin{array}{l}0.106 \\
(0.058-0.196)\end{array}$ & $<0.001$ \\
\hline
\end{tabular}

(Continued)
Table 6 (Continued).

\begin{tabular}{|l|l|l|l|l|}
\hline Variables & \multicolumn{2}{|l|}{ Univariate } & \multicolumn{2}{l|}{ Multivariate } \\
\cline { 2 - 5 } & OS HR(95\% Cl) & P-value & $\begin{array}{l}\text { OS HR(95\% } \\
\text { CI) }\end{array}$ & P-value \\
\hline $\begin{array}{l}\text { Treatment } \\
\text { regimen } \\
\text { With bortezomib } \\
\text { Without } \\
\text { bortezomib }\end{array}$ & $0.484(0.285-0.822)$ & $\mathbf{0 . 0 0 7}$ & & \\
\hline
\end{tabular}

Note: The bold font represents statistical significance.

Abbreviations: BMPC, bone marrow plasma cells ratio; D-S staging, Durie Salmon staging; BNP, brain natriuretic peptide; LDH, lactate dehydrogenase; ITE, initial therapeutic effect; OS, overall survival; HR, hazard ratio.

$\mathrm{BNP} \geqq 700 \mathrm{pg} / \mathrm{mL}$, and the presence of $\mathrm{AL}$ amyloidosis. Survival time was significantly longer in patients whose treatment regimen included bortezomib, initial therapeutic effect better than MR (Table 6). Cox regression adjusting for covariates was performed to evaluate the hazard ratio of each clinical character in symptomatic multiple myeloma, two factors having prognostic significance: $\mathrm{BNP} \geqq 700 \mathrm{pg} / \mathrm{mL}(\mathrm{HR}=2.455, P=0.004)$ and initial therapeutic effect better than MR $(\mathrm{HR}=0.106, P<0.001)$. Given that patients with amyloidosis had significantly shorter survival time than patients without amyloidosis (25.0 vs 42.0 months, $P=0.023$, Figure $1 \mathrm{~A}$ ), we further analyzed the impact of the type and number of organ involvement on the survival of all the patients with multiple myeloma. The results showed that survival time was significantly shorter with heart involvement (Figure 1B; median survival time was 25.0 vs 42.0 months, $P=0.024$ ), liver involvement (Figure $1 \mathrm{C}$; 11.0 vs 42.0 months, $P=0.013$ ).

\section{Survival Analyses of Patients with Smoldering Multiple Myeloma}

The median follow-up time was 48.0 months (19.3-76.6 months). Nineteen of the 36 patients (52.7\%) died during the follow-up. The overall median survival time for patients was 41.0 months (25.3-56.6 months). Then, we divided the patients by the clinical characteristics to study the factors affecting smoldering multiple myeloma patients' survival. Survival time was significantly shorter in patients with $\mathrm{ALP}>187.5 \mathrm{IU} / \mathrm{L}, \mathrm{BNP} \geqq 700 \mathrm{pg} / \mathrm{mL}$, and the presence of AL amyloidosis, significantly longer in patients whose treatment regimen included bortezomib, initial therapeutic effect better than MR (Table 7). Cox regression adjusting for covariates was performed to 

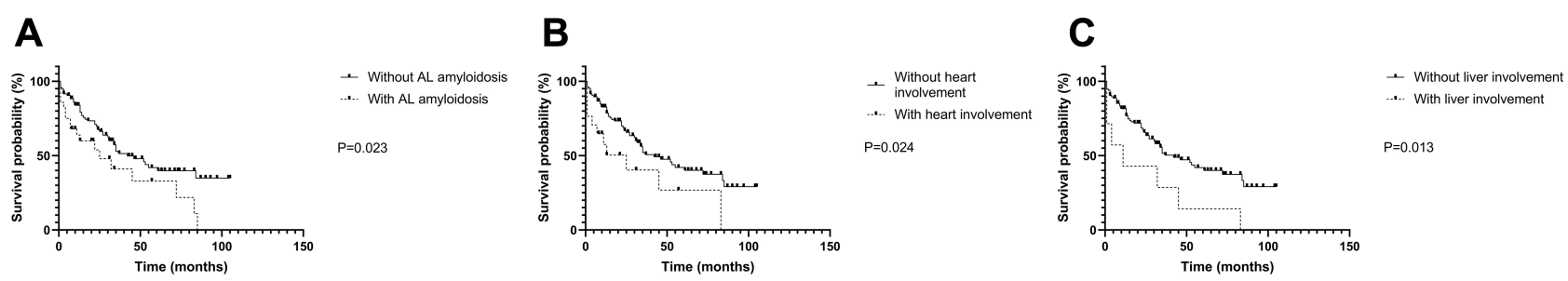

Figure I Kaplan-Meier curves demonstrating the impact of $A L$ amyloidosis on overall survival of symptomatic multiple myeloma. (A) Survival difference between symptomatic multiple myeloma patients with and without $A L$ amyloidosis. $P=0.023$. (B) Survival difference between $A L$ patients (symptomatic multiple myeloma) with and without heart involvement. $P=0.024$. (C) Survival difference between $A L$ patients (symptomatic multiple myeloma) with and without liver involvement. $P=0.013$.

evaluate the hazard ratio of each clinical character in smoldering multiple myeloma, three factors having prognostic significance: the presence of $\mathrm{AL}$ amyloidosis (HR=8.741, $P=0.002)$, treatment regimen with bortezomib $(\mathrm{HR}=0.249, P=0.024)$ and initial therapeutic effect better than $\mathrm{MR}(\mathrm{HR}=0.196, P=0.009)$. Given that patients with amyloidosis had significantly shorter survival time than patients without amyloidosis (15.0 vs not reach months, $P<0.001$, Figure $2 \mathrm{~A}$ ), we further analyzed the impact of the type and number of organ involvement on the survival of all the patients with smoldering multiple myeloma. The results showed that survival time was significantly shorter with heart involvement (Figure 2B; median survival time of 4.0 vs 64.0 months, $P<0.001$ ), kidney involvement (Figure 2C; 17.0 vs 64.0 months, $P=0.001$ ), liver involvement (Figure $2 \mathrm{D} ; 4.0$ vs 58.0 months, $P<0.001$ ), gastrointestinal tract involvement (Figure 2E; 1.0 vs 48.0 months, $P=0.013$ ) and $\geq 3$ organ involvement (Figure 2F; 5.0 vs 58.0 months, $P=0.001$ ).

\section{Correlation Analysis Between BNP and Cardiac Amyloidosis in Symptomatic Multiple Myeloma}

Kolmogorov-Smirnow test showed that BNP was not normally distributed. To investigate the relationship between BNP and cardiac amyloidosis, we performed the Spearman correlation test. We observed that BNP at diagnosis was significantly correlated with cardiac amyloidosis $(\mathrm{r}=0.496, P<0.001)$.

\section{Treatment Regimens, Initial Therapeutic Effect in Symptomatic or Smoldering Multiple Myeloma with AL Amyloidosis}

The previous results suggested that treatment regimen and initial therapeutic effect were significantly associated with the prognosis of symptomatic and smoldering multiple myeloma. The treatment regimens and initial therapeutic effect of the patients with symptomatic and smoldering multiple myeloma accompanied by $\mathrm{AL}$ amyloidosis are shown in Table 8. We further found that in patients with symptomatic multiple myeloma complicated by AL amyloidosis, the survival time of bortezomib group (45.0 vs 1.0 months, $P=0.013$, Figure $3 \mathrm{~A}$ ) and better ITE group (72.0 vs 4.0 months, $P<0.001$, Figure $3 \mathrm{~B}$ ) were longer. In addition, similarly, in patients with smoldering multiple myeloma complicated by $\mathrm{AL}$ amyloidosis, the survival time of bortezomib group (40.0 vs 1.0 months, $P<0.001$, Figure 3C) and better ITE group (not reach vs 18.0 months, $P=0.006$, Figure $3 \mathrm{D}$ ) were also longer.

\section{Discussion}

AL amyloidosis is a common complication of multiple myeloma. The incidence of $\mathrm{AL}$ amyloidosis increased significantly with the use of subcutaneous abdominal fat pad aspirates, ranging from $28 \%$ to $38 \%$ compared with the previously reported rate of $3-7 \% .^{18}$ Despite the increased detection rate of this complication, the difference in the clinical characteristics between myeloma patients with and without AL amyloidosis remains unclear. A previous study was not able to identify significant clinical differences between the two groups because most patients in this study had clinically occult $\mathrm{AL}$ amyloidosis. ${ }^{18}$ However, most patients in our study had symptomatic $\mathrm{AL}$ amyloidosis involving the heart, liver and kidney, consistent with the higher level of BNP, ALP and lower level of ALB. Interestingly, our study also found that only BNP and ALP were different between smoldering multiple myeloma with and without $\mathrm{AL}$ amyloidosis. Since these patients lacked the symptoms of multiple myeloma, they were often hospitalized due to the involvement of AL amyloidosis. However, we did not pay special attention to AL amyloidosis in clinical practice while they did not have symptoms, so delayed diagnosis often occurred. Even in the case of conscious screening for $\mathrm{AL}$ amyloidosis, the diagnosis of AL amyloidosis could be difficult. Clinically, subcutaneous fat aspiration biopsy, 
Table 7 Survival Analyses of 36 Patients with Smoldering Multiple Myeloma

\begin{tabular}{|c|c|c|c|c|}
\hline \multirow[t]{2}{*}{ Variables } & \multicolumn{2}{|l|}{ Univariate } & \multicolumn{2}{|l|}{ Multivariate } \\
\hline & $\begin{array}{l}\text { OS HR(95\% } \\
\mathrm{Cl})\end{array}$ & P-value & $\begin{array}{l}\text { OS HR(95\% } \\
\text { Cl) }\end{array}$ & P-value \\
\hline $\begin{array}{l}\text { Sex }=\text { male } \\
\text { Yes } \\
\text { No }\end{array}$ & $\begin{array}{l}1.312 \\
(0.470-3.663)\end{array}$ & 0.604 & & \\
\hline $\begin{array}{l}\text { Age } \\
\qquad \begin{array}{l}\geqq 65 \text { years } \\
<65 \text { years }\end{array}\end{array}$ & $\begin{array}{l}1.874 \\
(0.750-4.680)\end{array}$ & 0.179 & & \\
\hline $\begin{array}{l}\text { Higher BMPC } \\
\text { Yes } \\
\text { No }\end{array}$ & $\begin{array}{l}0.942 \\
(0.337-2.628)\end{array}$ & 0.909 & & \\
\hline $\begin{array}{l}\text { Higher LDH } \\
\text { Yes } \\
\text { No }\end{array}$ & $\begin{array}{l}2.040 \\
(0.580-7.175)\end{array}$ & 0.267 & & \\
\hline $\begin{array}{l}\text { Severe } \\
\text { hypoalbuminemia } \\
\text { Yes } \\
\text { No }\end{array}$ & $\begin{array}{l}1.818 \\
(0.67 \mid-4.925)\end{array}$ & 0.239 & & \\
\hline $\begin{array}{l}\text { ALP>187.5IU/L } \\
\text { Yes } \\
\text { No }\end{array}$ & $\begin{array}{l}6.951 \\
(1.710-28.252)\end{array}$ & 0.007 & & \\
\hline $\begin{array}{l}B N P \geqq 700 \mathrm{pg} / \mathrm{mL} \\
\text { Yes } \\
\text { No }\end{array}$ & $\begin{array}{l}8.871 \\
(2.732-28.811)\end{array}$ & $<0.001$ & & \\
\hline $\begin{array}{l}\text { AL amyloidosis } \\
\text { Yes } \\
\text { No }\end{array}$ & $\begin{array}{l}6.579 \\
(2.090-20.708)\end{array}$ & 0.001 & $\begin{array}{l}8.741 \\
(2.254-33.896)\end{array}$ & 0.002 \\
\hline $\begin{array}{l}\text { Better ITE } \\
\text { Yes } \\
\text { No }\end{array}$ & $\begin{array}{l}0.107 \\
(0.039-0.295)\end{array}$ & $<0.001$ & $\begin{array}{l}0.196 \\
(0.058-0.660)\end{array}$ & 0.009 \\
\hline $\begin{array}{l}\text { Treatment regimen } \\
\text { With bortezomib } \\
\text { Without } \\
\text { bortezomib }\end{array}$ & $\begin{array}{l}0.176 \\
(0.066-0.47 I)\end{array}$ & 0.001 & $\begin{array}{l}0.249 \\
(0.075-0.835)\end{array}$ & 0.024 \\
\hline
\end{tabular}

Note: The bold font represents statistical significance.

Abbreviations, BMPC, bone marrow plasma cells ratio; D-S staging, Durie Salmon staging; BNP, brain natriuretic peptide; LDH, lactate dehydrogenase; ITE, Initial therapeutic effect; OS, overall survival; HR, hazard ratio.

biopsy of bone marrow and gastrointestinal mucosa or rectal are recommended for the diagnosis of $\mathrm{AL}$ amyloidosis. ${ }^{23}$ Although clinically affected organ biopsy has a higher positive rate, its application is limited due to its larger trauma. In our study, many patients with renal biopsies suggesting AL amyloidosis had negative results of bone marrow biopsies or subcutaneous abdominal fat pad aspirates. It suggests that it is unreliable to use bone marrow biopsy or subcutaneous abdominal fat pad aspirates as a screening test for AL amyloidosis in patients with smoldering multiple myeloma. Therefore, promoting affected organ biopsy is important for the diagnosis of $\mathrm{AL}$ amyloidosis in smoldering multiple myeloma. Because the bone marrow plasma cells of smoldering multiple myeloma presented focal distribution, it is likely that the proportion of BMPC in the first bone marrow puncture could not meet the diagnostic criteria for smoldering multiple myeloma. In this way, it was likely to be misdiagnosed as AL amyloidosis alone. However, the prognosis of AL amyloidosis with BMPC more than 10\% including symptomatic and smoldering multiple myeloma is significantly worse than that of AL amyloidosis alone. ${ }^{24,25}$ In our study, repeated bone penetration could increase the diagnosis rate of smoldering multiple myeloma. Therefore, it is recommended to repeat the bone marrow puncture in such patients to diagnose smoldering multiple myeloma.

Prior studies have shown the predominance of $\lambda$ lightchain isotype in patients with primary systemic amyloidosis, a finding that has been attributed to the greater "amyloidogenicity" of the $\lambda$ chains. $^{26}$ The amyloidogenicity predominance of $\lambda$ light chain was observed in patients with multiple myeloma complicated by symptomatic AL amyloidosis rather than occult $\mathrm{AL}$ amyloidosis. ${ }^{18,19}$ In our study, we also observed more patients of $\lambda$-type multiple myeloma with AL amyloidosis than $\kappa$-type multiple myeloma. $\lambda$-type multiple myeloma may be a high-risk factor for AL amyloidosis during the disease course, which may due to the broken balance of the light-chain removal and deposition speed rather than the higher ability of the $\lambda$ light chain to cause AL amyloidosis. ${ }^{18}$ Previous studies suggested that the higher incidence of liver involvement and severe renal impairment were found in $\kappa$-type amyloidosis than in $\lambda$-type amyloidosis. $^{27}$ In our study, $\kappa$-type AL amyloidosis had higher incidence of BNP $\geqq 700 \mathrm{pg} / \mathrm{mL}$ and $\mathrm{Scr} \geqq 176.8 \mu \mathrm{mol} /$ $\mathrm{L}$ than $\lambda$-type AL amyloidosis, suggesting cardiac amyloidosis and renal insufficiency. Therefore, the incidence of AL amyloidosis in $\kappa$-type multiple myeloma is lower but more severe than $\lambda$-type multiple myeloma. There are two reasons for this situation: 1) the involvement of amyloidosis is related to the potential special biology of the type of light chains, with previous studies highlighting the relationship between immunoglobulin light-chain variable gene and the number and severity of involved organs of amyloidosis. ${ }^{28}$ 2) The dFLC included in the 2012 Mayo Clinical AL Amyloidosis Staging System suggested that the severity of organ involvement is positively correlated with the level of involved light chains. ${ }^{15}$ The level of involved light chain in $\kappa$ type 

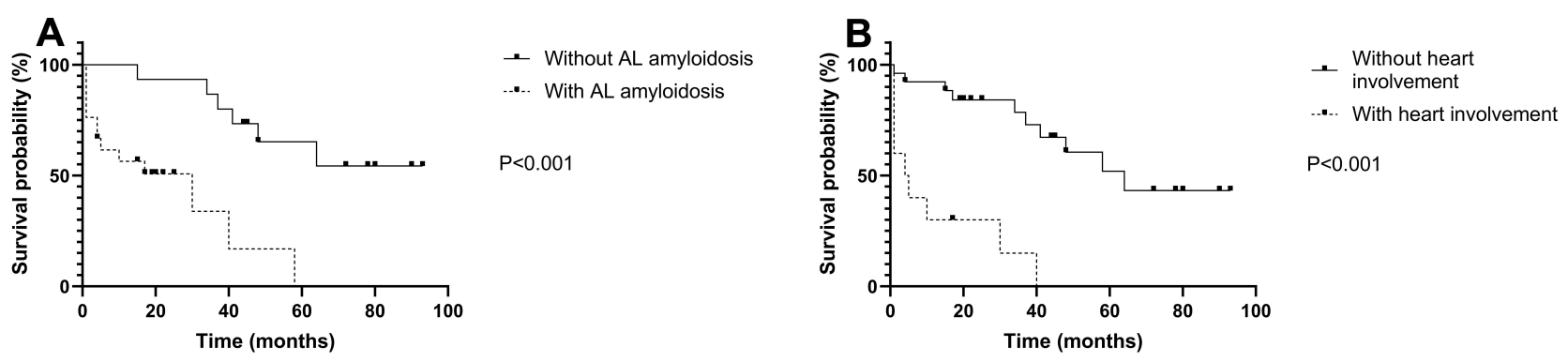

-.. With heart involvement

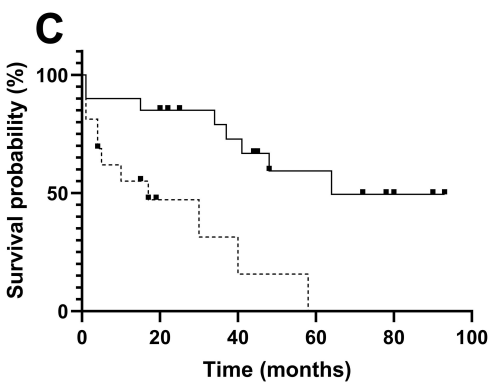

_. Without kidney

involvement

-.. With kidney involvement

$\mathrm{P}=0.001$

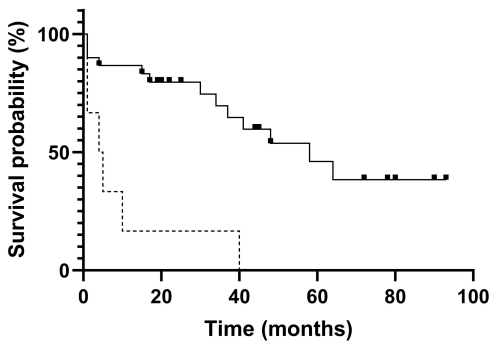

- Without liver involvemen

-.. With liver involvement

$\mathrm{P}<0.001$
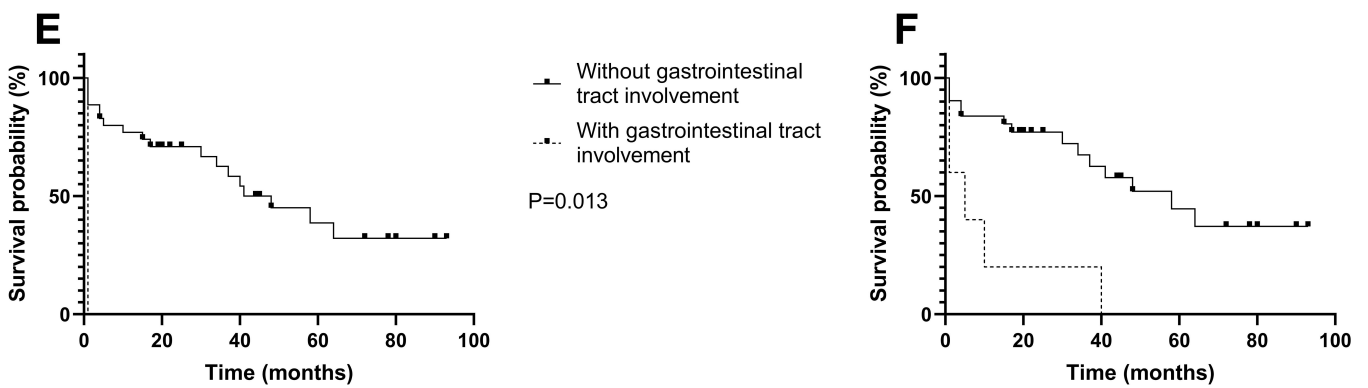
- Without gastrointestinal tract involvement
.. With gastrointestinal tract involvement
$\mathrm{P}=0.013$

Figure 2 Kaplan-Meier curves demonstrating the impact of $A L$ amyloidosis on overall survival of smoldering multiple myeloma. (A) Survival difference between patients with and without $A L$ amyloidosis in smoldering multiple myeloma patients. $P<0.00 \mathrm{I}$. (B) Survival difference between $A L$ patients (in smoldering multiple myeloma patients) with and without heart involvement. $P<0.00$ I. (C) Survival difference between AL patients (in smoldering multiple myeloma patients) with and without kidney involvement. $P=0.00$ I. (D) Survival difference between AL patients (in smoldering multiple myeloma patients) with and without liver involvement. $P<0.00 \mathrm{I}$. (E) Survival difference between $\mathrm{AL}$ patients (in smoldering multiple myeloma patients) with and without gastrointestinal tract involvement. $P=0.013$. (F) Survival difference between $A L$ patients (in smoldering multiple myeloma patients) with different number of organ involvement. $P=0.00 \mathrm{I}$.

amyloidosis is higher than $\lambda$ type amyloidosis, ${ }^{28}$ resulting in more severe organ damage.

There are a few studies to explore the prognostic impact of AL amyloidosis in multiple myeloma. Early studies found poor prognosis in patients with multiple myeloma accompanied by $\mathrm{AL}$ amyloidosis, with a median survival time of 1.1 VS 2.9 years in patients without AL amyloidosis. ${ }^{16,19}$ Some researchers found that AL amyloidosis in patients with multiple myeloma was an independent adverse prognostic factor, regardless of the presence of amyloid organ involvement at the time of diagnosis. ${ }^{16}$ Besides, Bahlis found that while occult amyloidosis had no impact on the outcome of multiple myeloma, the presence of symptomatic amyloidosis worsened the prognosis of multiple myeloma. ${ }^{17}$ However, one study found that neither occult amyloidosis (median survival time 59 months) nor symptomatic amyloidosis (median survival time 38 months) affected the prognosis of multiple myeloma. ${ }^{18}$ This result may be caused by the intensive treatment of autologous stem cell transplantation with highdose melphalan pretreatment in these patients which eliminated the adverse prognostic effect of AL amyloidosis on multiple myeloma. In another study, from among 4319 patients with a diagnosis of MM with at least 6 months of follow-up, 47selected patients were diagnosed with AL amyloidosis. Although the overall survival time of selected patients was 68.5 months, the survival time after AL amyloidosis diagnosis was only 9.1 months. ${ }^{19}$ In our study, whether it is symptomatic multiple myeloma or smoldering multiple myeloma, the survival time in patients with $\mathrm{AL}$ amyloidosis was shorter than those without AL amyloidosis. Further, Cox regression identified AL amyloidosis as an independent significant risk factor for poor prognosis in smoldering multiple myeloma after adjustment of other risk factors. In primary systemic amyloidosis, BU staging system including BNP and CTNI which had the same effectiveness as the 2004 Mayo Clinical AL Amyloidosis Staging System 
Table 8 Treatment Regimens and Initial Therapeutic Effect in Symptomatic and Smoldering Multiple Myeloma with AL Amyloidosis

\begin{tabular}{|l|l|l|l|l|}
\hline & \multicolumn{2}{|l|}{$\begin{array}{l}\text { Symptomatic } \\
\text { Multiple } \\
\text { Myeloma }\end{array}$} & \multicolumn{2}{l|}{$\begin{array}{l}\text { Smoldering } \\
\text { Multiple } \\
\text { Myeloma }\end{array}$} \\
\cline { 2 - 5 } & $\begin{array}{l}\text { Better } \\
\text { ITE }\end{array}$ & $\begin{array}{l}\text { Worse } \\
\text { ITE }\end{array}$ & $\begin{array}{l}\text { Better } \\
\text { ITE }\end{array}$ & $\begin{array}{l}\text { Worse } \\
\text { ITE }\end{array}$ \\
\hline $\begin{array}{l}\text { Treated with } \\
\text { bortezomib }(n=37)\end{array}$ & 17 & 7 & 10 & 3 \\
\hline $\begin{array}{l}\text { Treated without } \\
\text { bortezomib }(n=12)\end{array}$ & 2 & 2 & 1 & 7 \\
\hline All patients $(n=49)$ & 19 & 9 & 11 & 10 \\
\hline
\end{tabular}

Abbreviation: ITE, initial therapeutic effect.

to predict the survival time of $\mathrm{AL}$ amyloidosis. ${ }^{29} \mathrm{BNP}$ had the same value as NT-proBNP in assessing the severity of cardiac amyloidosis. ${ }^{30}$ In our study, BNP $\geqq 700 \mathrm{pg} / \mathrm{mL}$ was an adverse prognostic factor for symptomatic multiple myeloma. In addition, BNP was significantly correlated with cardiac amyloidosis. Therefore, we believe that AL amyloidosis especially those with the heart involvement has an adverse impact on the prognosis of symptomatic multiple myeloma.
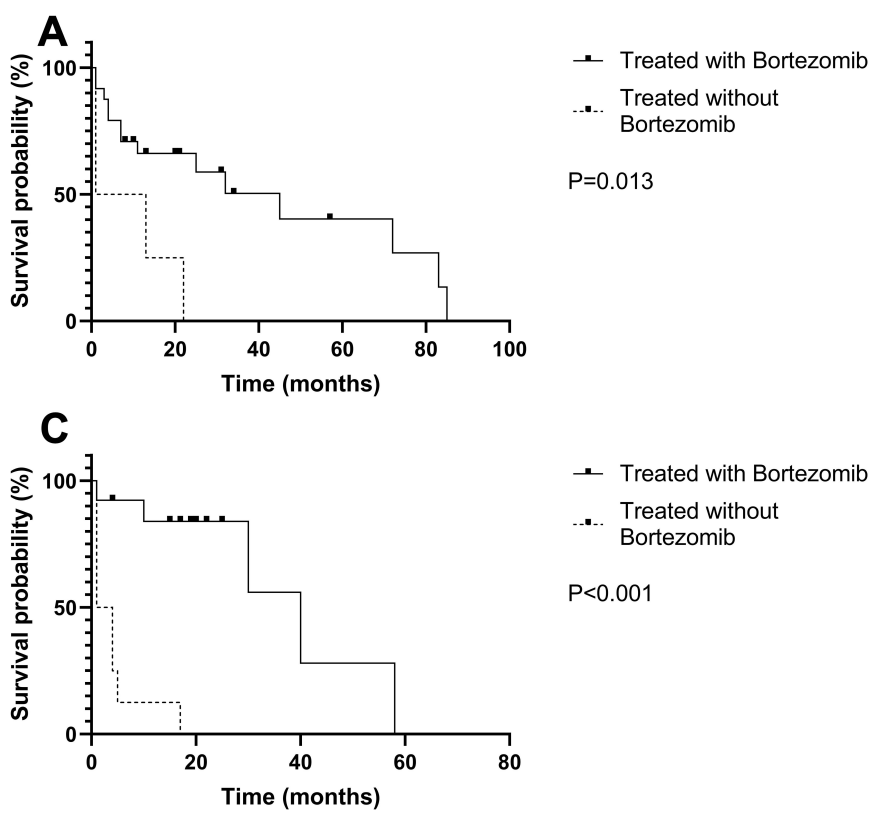

The prognosis of patients with amyloidosis is largely determined by the number of organs involved and the severity of the involvements. ${ }^{31}$ Among patients with primary systemic amyloidosis, amyloidosis involving the heart is the worst adverse prognostic factor. ${ }^{32}$ The median survival time of patients without heart failure caused by cardiac amyloidosis was 30 months, while congestive heart failure caused by cardiac amyloid deposition reduced the survival time to $4-8$ months. ${ }^{32}$ In a retrospective study, multiple myeloma patients with cardiac amyloidosis had a much shorter overall survival time than patients without cardiac amyloidosis (4.3 months vs 13 months). ${ }^{19}$ Same in our study, cardiac amyloidosis was the main cause of death for all multiple myeloma patients complicated by $\mathrm{AL}$ amyloidosis. We noticed shorter survival time in all multiple myeloma patients with liver involvement than those with heart involvement. This may be caused by multiorgan involvement, as most patients with liver involvement in this study also had cardiac amyloidosis. Our study showed that patients with multiple myeloma accompanied by AL amyloidosis often died of the cardiac amyloidosis, renal failure and gastrointestinal tract hemorrhage caused by $\mathrm{AL}$ amyloidosis rather than other multiple myeloma related deaths. We also found multiple organs' involvement leads to a shorter median survival time in smoldering
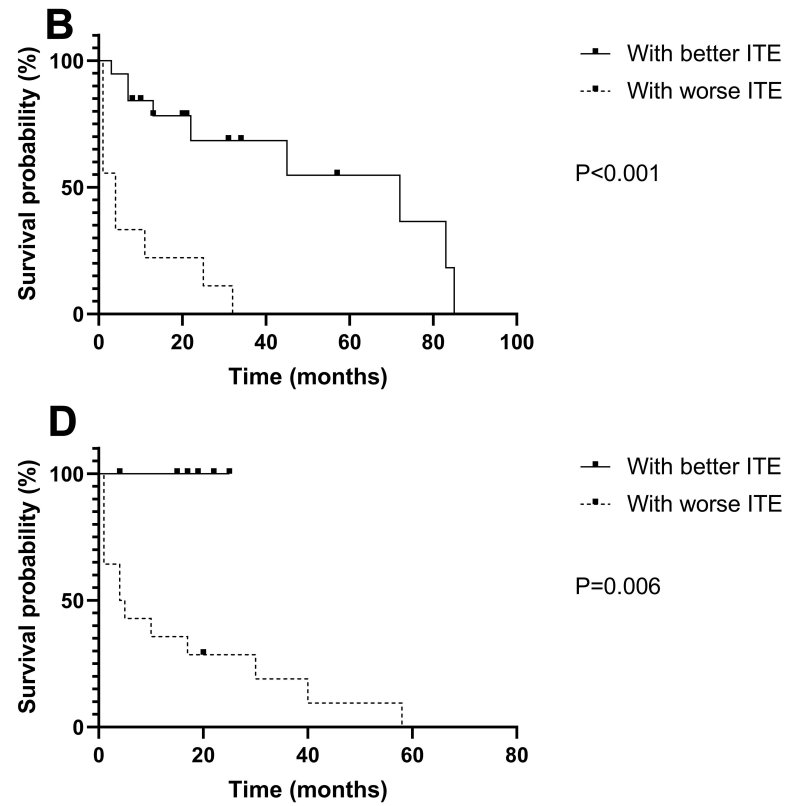

Figure 3 Kaplan-Meier curves demonstrating the impact of treatment regimens, initial therapeutic effect on overall survival of symptomatic and smoldering multiple myeloma with AL amyloidosis. (A) Survival difference between bortezomib group and non-bortezomib group in symptomatic multiple myeloma with AL amyloidosis. $P=0.013$. (B) Survival difference between better ITE group and worse ITE group in symptomatic multiple myeloma with $A L$ amyloidosis. $P<0.00 \mathrm{I}$. (C) Survival difference between bortezomib group and non-bortezomib group in smoldering multiple myeloma with AL amyloidosis. $P<0.00$ I. (D) Survival difference between better ITE group and worse ITE group in smoldering multiple myeloma with $\mathrm{AL}$ amyloidosis. $P=0.006$.

Abbreviation: ITE, initial therapeutic effect. 
multiple myeloma. No similar statistical difference was observed in symptomatic multiple myeloma, this might be due to the insufficient number of cases. Therefore, to some extent, multi-organs involvement might be the reason why amyloidosis affected the prognosis of multiple myeloma.

We could see that AL amyloidosis had an adverse effect on the prognosis of symptomatic and smoldering multiple myeloma. However, what we need to pay attention to is that renal involvement and gastrointestinal tract involvement had an impact on the prognosis of smoldering multiple myeloma but not on symptomatic multiple myeloma. In addition, the survival time of smoldering multiple myeloma with amyloidosis (15.0 months) is shorter than that of symptomatic multiple myeloma with amyloidosis (25.0 months). Logically, smoldering multiple myeloma had a better prognosis as an early lesion of symptomatic multiple myeloma. However, the situation was exactly the opposite in our study. Therefore, we speculated that AL amyloidosis had a greater impact on the prognosis of smoldering multiple myeloma than symptomatic multiple myeloma. The potential reason for this situation might be the lag in diagnosis. The lack of CRAB symptoms of multiple myeloma, which took a long time from onset to diagnosis, resulted in the more extensive of amyloidosis and the delay in treatment intervention. Therefore, in clinical practice, the early diagnosis of such patients is particularly important. Due to the poor prognosis, difficulty in diagnosis and diagnostic lag of smoldering multiple myeloma combined with AL amyloidosis, we need to find better biomarkers to screen such patients in the future.

Anti-plasma cell therapy is the cornerstone of the treatment of primary amyloidosis. Organ recovery is significantly related to the depth of hematological remission achieved. $^{33}$ The deeper the hematological remission, the more likely organ recovery will occur. ${ }^{33}$ Moreover, the deeper the organ response achieved, the longer the survival. For example, the respective 10-year OS rates for those having a reduction in NT-proBNP by $>60 \%$ (very good partial organ response), 31-60\% (partial organ response), and $\leq 30 \%$ (no response) reduction from baseline were $68 \%$, $39 \%$, and $24 \%$, respectively. ${ }^{33}$ In our study, we also found that the survival time of patients with amyloidosis who had better ITE was longer than that of worse ITE. However, we found that patients with amyloidosis had the same degree of hematological remission but shorter survival time than patients without amyloidosis, suggesting that the therapeutically achieving hematological remission does not completely improve the prognosis. There were two reasons for this situation: 1) The organ damage caused by AL amyloidosis is irreversible and 2) the therapeutic effect did not reach the level of preventing the continued deposition of amyloid. Given that organ involvement is the main cause of death in multiple myeloma patients with AL amyloidosis, organ remission as the goal of treatment may lead to better prognosis for these patients. In multiple myeloma, the initial therapeutic effect with bortezomib-based treatment was better than that of traditional chemotherapy regimens including VAD and Melphalan-based treatment, which could improve the prognosis of multiple myeloma. ${ }^{34}$ In $\mathrm{AL}$ amyloidosis, the same phenomenon was also observed. ${ }^{35}$ Similarly, in our study, the survival time of bortezomib group was longer than that of non-bortezomib group in patients with multiple myeloma accompanied by AL amyloidosis, suggesting that bortezomib could improve the prognosis of such patients. Among the bortezomib-based chemotherapy regimens, the treatment efficiency of cyclophosphamide-bortezomib and dexamethasone (Cybor-D) was as high as $94 \%$ in $\mathrm{AL}$ amyloidosis. $^{35}$ In our study, due to the small number of cases using this regimen, there was no basis to say that Cybor-D was better than BD for the patients with multiple myeloma accompanied by $\mathrm{AL}$ amyloidosis, and further exploration is needed in the future. Besides, whether new drugs such as Lenalidomide, CD38 monoclonal antibody, and autologous stem cell transplantation applied to multiple myeloma with $\mathrm{AL}$ amyloidosis can improve the prognosis of these patients requires further research.

\section{Conclusions}

$\mathrm{AL}$ amyloidosis is an independent poor prognostic factor for not only symptomatic multiple myeloma but also smoldering multiple myeloma, mainly because AL amyloidosis involves important organs, especially the heart. In addition, we believe that AL amyloidosis probably has a greater impact on the prognosis of smoldering multiple myeloma than symptomatic multiple myeloma. In patients with smoldering multiple myeloma, we should more actively screen for AL amyloidosis. Since smoldering multiple myeloma with AL amyloidosis has a poor prognosis and is difficult to diagnose, repeated bone penetration and biopsy of affected organs should be promoted in such patients. Bortezomib can improve the prognosis of such patients. Bortezomib-based treatment can be recommended for these patients. However, more treatment options are needed to obtain deeper organ response to improve the prognosis of this group of patients. 


\section{Abbreviations}

AL amyloidosis, amyloid light-chain amyloidosis; BNP, brain natriuretic peptide; ALP, alkaline phosphatase; ALB, albumin; $\mathrm{Hb}$, hemoglobin; $\mathrm{LDH}$, lactate dehydrogenase; $\mathrm{Ca}$, calcium; Scr, serum creatinine; BMPC, bone marrow plasma cells; dFLC, difference between involved and uninvolved serum free light chains; NT-proBNP, N terminal pro B type natriuretic peptide; CTNI, cardiac troponin I; OS, overall survival; HR, hazard ratio; D-S stage, Durie Salmon stage; ITE, Initial therapeutic effect; PD, progressive disease; SD, stable disease; MR, minimal response; PR, partial response; VGPR, very good partial remission; $\mathrm{CR}$, complete remission; sCR, stringent complete remission; Cybor-D, cyclophosphamide-bortezomib and dexamethasone.

\section{Data Sharing Statement}

Not applicable.

\section{Ethics Approval and Consent to Participate}

The Ethics Committee of Peking University First Hospital provided ethical approval (NO. 2017[1304]). Written informed consent for collecting details was obtained from each patient. This study was conducted in accordance with the Declaration of Helsinki.

\section{Consent for Publication}

Not applicable.

\section{Author Contributions}

All authors made substantial contributions to conception and design, acquisition of data, or analysis and interpretation of data; took part in drafting the article or revising it critically for important intellectual content; agreed to submit to the current journal; gave final approval of the version to be published; and agree to be accountable for all aspects of the work.

\section{Funding}

This work was supported by the Beijing Municipal Science Technology Commission (No. Z1911000066 19026).

\section{Disclosure}

The authors declare that they have no conflicts of interest for this work.

\section{References}

1. Landgren O, Rajkumar SV. New developments in diagnosis, prognosis, and assessment of response in multiple myeloma. Clin Cancer Res. 2016;22(22):5428-5433. doi:10.1158/1078-0432.CCR-16-0866

2. Palumbo A, Avet-Loiseau H, Oliva S, et al. Revised international staging system for multiple myeloma: a report from international myeloma working group. J Clin Oncol. 2015;33:2863-2869.

3. Rajkumar SV. Multiple myeloma: 2018 update on diagnosis, riskstratification, and management. Am J Hematol. 2018;93:981-1114.

4. Kastritis E, Terpos E, Moulopoulos L, et al. Extensive bone marrow infiltration and abnormal free light chain ratio identifies patients with asymptomatic myeloma at high risk for progression to symptomatic disease. Leukemia. 2013;27:947-953.

5. Rajkumar SV. Updated diagnostic criteria and staging system for multiple myeloma. Am Soc Clin Oncol Educ Book Am Soc Clin Oncol Annual Meeting. 2016;35:e418-23.

6. Acquah ME, Hsing AW, McGuire V, Wang S, Birmann B, DeiAdomakoh Y. Presentation and survival of multiple myeloma patients in Ghana: a review of 169 cases. Ghana Med J. 2019;53:52-58.

7. Dispenzieri A, Kyle RA, Katzmann JA, et al. Immunoglobulin free light chain ratio is an independent risk factor for progression of smoldering (asymptomatic) multiple myeloma. Blood. 2008;111:785-789.

8. Tian C, Wang L, Wu L, et al. Clinical characteristics and prognosis of multiple myeloma with bone-related extramedullary disease at diagnosis. Biosci Rep. 2018;38.

9. González-Calle V, Slack A, Keane N, et al. Evaluation of Revised International Staging System (R-ISS) for transplant-eligible multiple myeloma patients. Ann Hematol. 2018;97:1453-1462.

10. Lakshman A, Rajkumar SV, Buadi FK, Binder M. Risk stratification of smoldering multiple myeloma incorporating revised IMWG diagnostic criteria. 2018;8:59.

11. Ryšavá R. AL amyloidosis: advances in diagnostics and treatment. Nephrol Dialysis Transplant. 2018;34.

12. Desport E, Bridoux F, Sirac C, et al. AL Amyloidosis. Orphanet J Rare Dis. 2012;7:54.

13. Vela-Ojeda J, García-Ruiz Esparza MA, Padilla-González Y, et al. Multiple myeloma-associated amyloidosis is an independent high-risk prognostic factor. Ann Hematol. 2009;88:59-66.

14. Dispenzieri A, Gertz MA, Kyle RA, et al. Serum cardiac troponins and N-terminal pro-brain natriuretic peptide: a staging system for primary systemic amyloidosis. J Clin Oncol. 2004;22:3751-3757.

15. Kumar S, Dispenzieri A, Lacy MQ, et al. Revised prognostic staging system for light chain amyloidosis incorporating cardiac biomarkers and serum free light chain measurements. $J$ Clin Oncol. 2012;30:989-995.

16. Vela-Ojeda J, Esparza GR, Padilla-González Y, et al. Multiple myeloma-associated amyloidosis is an independent high-risk prognostic factor. Ann Hematol. 2009;88:59-66.

17. Bahlis NJ, Lazarus HM. Multiple myeloma-associated AL amyloidosis: is a distinctive therapeutic approach warranted? Bone Marrow Transplant. 2006;38:7-15.

18. Desikan KR, Dhodapkar MV, Hough A, et al. Incidence and Impact of Light Chain Associated (AL) amyloidosis on the prognosis of patients with multiple myeloma treated with autologous transplantation. Leuk Lymphoma. 1997;27:315-319.

19. Madan S, Dispenzieri A, Lacy MQ, et al. Clinical features and treatment response of Light Chain (AL) amyloidosis diagnosed in patients with previous diagnosis of multiple myeloma. Mayo Clinic Proc. 2010;85:232-238.

20. Rajkumar SV, Dimopoulos MA, Palumbo A, et al. International Myeloma Working Group updated criteria for the diagnosis of multiple myeloma. Lancet Oncol. 2014;15:e538-e48. 
21. Grateau G, Solomon A, Sezer O, et al. Definition of organ involvement and treatment response in immunoglobulin light chain amyloidosis (AL): a consensus opinion from the 10th International Symposium on Amyloid an Amyloidosis, Tours, France, 18-22 April 2004. Clinica Chimica Acta Int J Clin Chem. 2005;356:1-8.

22. Kumar S, Paiva B, Anderson KC, et al. International Myeloma Working Group consensus criteria for response and minimal residual disease assessment in multiple myeloma. Lancet Oncol. 2016;17: e328-e46.

23. Rijswijk MHV. Diagnostic accuracy of subcutaneous abdominal fat tissue aspiration for detecting systemic amyloidosis and its utility in clinical practice. Arth Rheumatol. 2014;54:2015-2021.

24. Zhang CL, Qiu Y, Shen KN, et al. Clinical presentation and prognosis of immunoglobulin light-chain amyloidosis with high percentage of bone marrow plasma cells. Leuk Res. 2019;81:19-24.

25. Tovar N, Rodríguez-Lobato LG. Bone marrow plasma cell infiltration in light chain amyloidosis: impact on organ involvement and outcome. 2018;25:79-85.

26. Solomon A, Weiss DT, Kattine AA. Nephrotoxic potential of Bence Jones proteins. $N$ Engl J Med. 1991;324:1845-1851.

27. Huang X, Wang Q, Jiang S, Chen W, Zeng C, Liu Z. The clinical features and outcomes of systemic AL amyloidosis: a cohort of 231 Chinese patients. Clin Kidney J. 2014;8:120-126.
28. Sidiqi MH, Aljama MA, Muchtar E, et al. Light chain type predicts organ involvement and survival in $\mathrm{AL}$ amyloidosis patients receiving stem cell transplantation. 2018;2:769-776.

29. Lilleness B, Ruberg FL. Development and validation of a survival staging system incorporating BNP in patients with light chain amyloidosis. 2019;133:215-223.

30. Tomlinson R, Matigian N, Mollee P. Validation of the Boston University staging system in AL amyloidosis. Amyloid. 2019;26:125-127.

31. Kastritis E, Dimopoulos MA. Prognosis and risk assessment in AL amyloidosis - there and back again. $\mathrm{Br} J$ Haematol. 2017; 177:343-345.

32. Gertz M. Amyloidosis: prognosis and treatment. Semin Arthritis Rheum. 1994;24:124-138.

33. Muchtar E, Dispenzieri A, Leung N. Depth of organ response in AL amyloidosis is associated with improved survival: grading the organ response criteria. 2018;32:2240-2249.

34. Meng X, Juan HE, Yan LI, et al Comparative Study of the curative effects of BD Regimen and VAD regimen in the treatment of multiple myeloma. J China Med Univ. 2011;40:352-356.

35. Gertz MA. Immunoglobulin light chain amyloidosis: 2020 update on diagnosis, prognosis, and treatment. Am J Hematol. 2020;95:848-860.

\section{Publish your work in this journal}

Cancer Management and Research is an international, peer-reviewed open access journal focusing on cancer research and the optimal use of preventative and integrated treatment interventions to achieve improved outcomes, enhanced survival and quality of life for the cancer patient.
The manuscript management system is completely online and includes a very quick and fair peer-review system, which is all easy to use. Visit http://www.dovepress.com/testimonials.php to read real quotes from published authors. 